\title{
Dvojna tradicija latinice u Hrvata: povijesni pregled
}

\author{
ELŐD DUDÁS*
}

ELTE BTK Szláv Filológiai Tanszék, H-1088 Budapest, Múzeum krt. 4/D., Magyarország

Received: 24 September 2020 • 17 November 2020

(C) 2021 The Author

\section{SAŽETAK}

Povijest hrvatske latinične grafije je iznimno bogata i istraživačima pruža brojne zanimljivosti, mada je dosad bilo objavljeno veoma malo djela o toj temi. Prvi takav pokušaj je bio Maretićeva povijest latiničke grafije (MAretić 1889). Svakako treba istaknuti rad Milana Moguša i Josipa Vončine (Moguš-Vončina 1969) koji je u mnogočemu ispravio Maretićeve pogrešne tvrdnje. Također u posljednje vrijeme je bilo objelodanjeno nekoliko radova o povijesti latiničke grafije u Hrvata (KAPETANović 2005, FARKAš-ĆURAK 2016, FARKAš 2019). Kad se govori o istraživanju hrvatske latinice, nikako ne smijemo zaboraviti doprinos Lászla Hadrovicsa. On je bio jedini koji se usredotočio na detaljniji prikaz dvojnog razvoja latinice u Hrvata od samih početaka. U ovom ćemo radu ići njegovim tragovima, budući da je cilj našega rada predstavljanje dvojne tradicije hrvatske latinice i onog kulturnopovijesnog konteksta koji je okarakterizirao razvoj hrvatske grafije.

U razvoju latinice crkva je imala najvažniju ulogu. Crkva je bila i središte pismenosti u srednjem vijeku. Iz toga slijedi da izgovor određenih latinskih glasova je utjecao na razvoj grafije pojedinih nacionalnih jezika. U slučaju hrvatskog jezika sve to je još posebnije, budući da na južnom dijelu Hrvatske nalazimo jak talijanski i mletački utjecaj, a na sjevernom je dijelu, što naime poklapa s Zagrebačkom biskupijom, očit jak mađarski utjecaj. Južna je tradicija pratila talijanski način izgovora latinskih glasova, što je utjecalo i na razvoj latiničke grafije. S druge strane nalazimo mađarski način izgovora lat. /s/, tj. [S], [3] na sjevernom području. Ova dva sustava su stoljećima karakterizirali hrvatsku latiničnu grafiju, međutim od kraja XVI. stoljeća je bilo više pokušaja za primjenu mješovitog sustava, a jedino je bilo to uspješno u slavonskoj grafiji XVIII. stoljeća.

\footnotetext{
*Corresponding author. E-mail: dudas.elod@btk.elte.hu
} 


\section{KLUČNE RIJEČI}

hrvatski jezik, grafija, latinična grafija, povijesni pregled, dvojna tradicija, uporaba grafema, talijanski utjecaj, talijanska grafija, mađarski utjecaj, mađarska grafija

\section{UVOD}

Povijest hrvatske latinične grafije je iznimno bogata, mada je dosad bilo veoma malo pokušaja da se predstavi njezin povijesni razvoj od samih početaka do Gajeve pravopisne reforme. Svakako treba istaknuti Maretićevo djelo koje je prvi znanstveni pokušaj predstavljanja razvoja latinične grafije u Hrvata (Maretić 1889). Desetljećima je to djelo bilo jedini izvor za istraživače koji su se bavili poviješću hrvatske grafije. Sljedeći važni korak u istraživanju latinice u Hrvata bio je rad Milana Moguša i Josipa Vončine (Moguš-Vončına 1969). Njihov je pregled u mnogočemu dopunio Maretićevo djelo i istovremeno ukazao na neke njegove pogrešne tvrdnje. Istraživanje razvoja hrvatske latinice bilo je predmetom i nekoliko kraćih radova u prošlim desetljećima (npr. KAPETANOVIĆ 2005, VončINA 2002), a veće sinteze o razvoju hrvatske latinice još uvijek nedostaju. Iz prošlih godina svakako treba spomenuti rad autorica Loretane Farkaš i Silvije Ćurak u kojem prikazuju mađarsko-hrvatska grafijska prožimanja, posebice kajkavsku i slavonsku grafiju (FARKAš-ĆURAK 2016). Loretana Farkaš bavila se slavonskom grafijom XVIII. stoljeća i u samostalnom radu (FARKAš 2019). Kad se govori o istraživanju hrvatske latinice, nikako ne smijemo zaboraviti doprinos Lászla Hadrovicsa koji se različitim pitanjima razvoja hrvatske grafije bavio $\mathrm{u}$ više navrata. Svoje je rezultate objavio u znanstvenim časopisima i zbornicima (HADrovics 1942, Hadrovics 1944, Hadrovics 1951, Hadrovics 1966), a najvažniji su mu radovi ponovo objavljeni u posebnom izdanju, tj. u izabranim djelima profesora Hadrovicsa (Hadrovics 1994). On je bio jedini koji se usredotočio na detaljniji prikaz dvojnog razvoja latinice u Hrvata od samih početaka. U ovom ćemo radu ići njegovim tragovima, budući da je cilj našega rada predstavljanje dvojne tradicije hrvatske latinice i onog kulturnopovijesnog konteksta koji je okarakterizirao razvoj hrvatske grafije. Možemo se složiti s riječima profesora Hadrovicsa koji tvrdi da „[...] die Geschichte der kroatischen Rechtschreibung nicht als ein organisch zusammenhängendes Gebäude, sondern als ein mühsam zusammengelegtes Mosaik an“ (Hadrovics 1994: 8). Iz toga slijedi da je istraživanje kulturnopovijesnog konteksta izvodljivo tek uz poznavanje suvremene talijanske i mađarske tradicije koje su utjecale na razvoj latinice u Hrvata.

\section{OPĆENITO O LATINICI}

Latinica ili latinično pismo je etruščanskog podrijetla, mada i etruščansko pismo potječe iz grčke abecede zapadnog tipa (BALÁzs 1989: 118). Klasična latinica se sastoji od 23 slova: $a, b, c, d, e, f, g$, $h, i, k, l, m, n, o, p, q, r, s, t, u, x, y, z$. U klasičnoj latinskoj abecedi nedostaju slova $j \mathrm{i} v$. Ta dva slova je uveo u latinsku abecedu francuski humanist Petrus Remus, a proširila su se tek u drugoj polovici XVI. stoljeća (BALÁzs 1989: 119). Treba spomenuti i to da se fonemski sustav srednjovjekovnog vulgarnog latiniteta znatno razlikovao od onoga klasičnog latinskog jezika, a latinska abeceda nije mogla slijediti te promjene (BALÁzs 1989: 120). U povijesnom se razvoju latinice razlikuju tri 
razdoblja: 1. rimsko razdoblje (od VI./V. stoljeća prije Krista), 2. srednjovjekovno razdoblje (od VII./VIII. stoljeća), 3. moderno razdoblje (od XIV. stoljeća) (KAPETANOvić 2005: 463).

\section{POČECI LATINICE U HRVATA}

Latinica je bila treće pismo, uz glagoljicu i ćirilicu / bosančicu, koja se pojavila u povijesti hrvatske grafije u XIV. stoljeću. Prvi hrvatski tekst koji je pisan latinicom jest Red i zakon od primljen'ja na dil dobroga činjen'ja sestar naših reda svetoga otca našega Dominika u Zadru iz 1345. g. (Moguš 1993: 27). Iz druge polovice XIV. stoljeća imamo Šibensku molitvu (NyOMÁRKAY 2007: 72), najstariji spomenik hrvatskog pjesništva (Lukács 2008: 90), Korčulanski lekcionar i još neke kraće tekstove (Moguš 1993: 27), ali se latinica proširila tek tijekom XV. stoljeća (VINCE 1978: 72). Svakako treba spomenuti i pasionsku pjesmu Cantilena pro Sabatho iz druge polovice XIV. stoljeća koju je otkrio András Vízkelety u jednom latinskom zborniku u mađarskoj Nacionalnoj knjižnici Széchényi u Budimpešti. Pjesmu je hrvatskoj znanosti predstavio mađarski kroatist László Hadrovics (v. Hadrovics 1984), a u novije se vrijeme njezinim mjestom i ulogom u hrvatskoj srednjovjekovnoj književnosti bavio István Lukács (v. LukÁcs 2008: 86-98). Moramo istaknuti i činjenicu da su prepisivač te pasionske pjesme i autor Šibenske molitve ista osoba, tj. franjevac Paulus de Sibinico (Lukács 2008: 90). Međutim, i prije tih spomenika nalazimo tragove hrvatskog jezika pisanog latinicom. Tu mislimo na glose, na „riječi kojima se tumače nepoznate riječi u (inojezičnim) tekstovima između redaka ili na margini“ (KAPETANović 2005: 466). Hrvatskim jezikom pisane najstarije glose nalazimo u Radonovoj Bibliji (KapETANović 2005: 466). Naime, ne smijemo zaboraviti ni ona osobna i mjesna imena koja su također pisana latinicom u latinskim tekstovima i ispravama (Moguš 1993: 28), a koja su nastala čak i prije pojavljivanja glagoljice i ćirilice / bosančice. Ovi spomenici svjedoče o latinskoj pismenosti koja se njegovala u benediktinskim samostanima (KATIČIĆ 1998: 42).

Nakon prvih spomenika nastalo je više tekstova koji su pisani latinicom. Ovi kasniji latinični spomenici potječu iz srednje Dalmacije, tj. s čakavskog područja, a glede sadržaja dosta su različiti. Među njima nalazimo molitvenike, legende, žitije, ali i pravne i administrativne dokumente (OczKowA 2010: 144). Raširenost latiničkog pisma odražava se i u njegovoj pojavi početkom XV. stoljeća i u dubrovačkoj štokavskoj pismenosti umjesto ćirilice / bosančice (OczKowA 2010: 148).

Naravno, postavlja se i pitanje: zašto se pojavila latinica kao treće pismo Hrvata uz glagoljicu i ćirilicu / bosančicu? Milan Moguš to objašnjava činjenicom da je latinica ipak bila primjenjivana za zapisivanje hrvatskih vlastitih imena i prije prvih latiničnih spomenika, dakle u latinskim ispravama (Moguš 1993: 28). To znači da je latinično pismo imalo neku tradiciju i prije glagoljice i ćirilice / bosančice u Hrvata i ova je tradicija bila polazište za njegov kasniji razvoj.

\section{OPĆENITO O LATINICI U HRVATA}

Povijesni razvoj latinice u Hrvata možemo podijeliti na dva razdoblja: 1) srednjovjekovno razdoblje i 2) novovjekovno razdoblje (KapeTAnović 2005: 463). Novovjekovno razdoblje možemo podijeliti na dopreporodnu / nenormiranu latinicu i poslijepreporodnu / normiranu latinicu (KAPETANOvić 2005: 463). U nastavku ćemo se usredotočiti na srednjovjekovno razdoblje. 
Povijest i razvoj latinice bili su u tijesnoj vezi s crkvom i crkvenim životom u europskih naroda, odnosno u vezi s izgovorom određenih latinskih glasova (VINCE 1978: 73, Hadrovics 1994: 8) koji se razlikovao po jezicima, tradicijama, a u slučaju hrvatskog jezika čak i po pokrajinama. Hrvatsku je srednjovjekovnu latinicu karakterizirala uporaba više grafema za označavanje istoga fonema. To nije bilo značajno samo za hrvatsku grafiju, nego i za one dvije grafije (usp. Maraschio 1994: 156) koje su znatno utjecale na razvoj hrvatske grafije kroz stoljeća, a to su talijanska i mađarska srednjovjekovna grafija.

Najveću je teškoću predstavljalo označavanje onih fonema koji ne postoje u latinskome je-

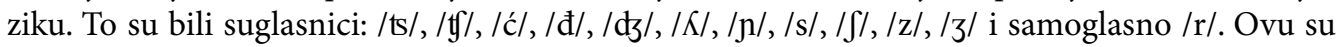
teškoću rješavali na različite načine, npr. uporabom dijakritičkih znakova ili kombinacijom više slova, tako da su nastali dvoslovi i troslovi. Dijakritički su znakovi bili najčešće primjenjivani za označavanje palatalnih suglasnika (Moguš 1993: 29). Unatoč tomu vidi se tendencija prema monografskim rješenjima (Moguš 1993: 28), tj. da jedan znak označava jedan fonem. Takav sustav nalazimo u glagoljici i ćirilici / bosančici u kojima jedan znak / grafem predstavlja jedan fonem.

Sljedeća tablica prikazuje koliko grafema je bilo u uporabi u povijesti hrvatske latinične grafije, zapravo od 1495. g. do 1833. g., za označavanje pojedinih fonema koji nedostaju u latinskom jeziku. Tablica je sastavljena prema radu Josipa Vončine:

\begin{tabular}{|c|c|}
\hline Fonem & Grafemi \\
\hline $\mid \mathrm{tg} /$ & c, ch, chi, ci, cj, cs, csi, csj, csy, cf, cfi, cz, ç, çi, tch, z, zh, zi \\
\hline /ćl & $\begin{array}{l}\text { cch, cchi, ch, chi, chj, chy, ck, cki, cs, csi, cf, cfi, k, ki, ky, tch, } \\
\text { tchi, tchj, tchy, tj, tky, ty }\end{array}$ \\
\hline /d/ & ch, chi, dg, dgi, dgj, di, dj, dy, g, gh, ghi, ghj, gi, gj, gy \\
\hline$/ K /$ & chl, gl, gli, glj, gly, li, lj, ly, l \\
\hline$/ \mathrm{n} /$ & chn, gn, gni, gnj, gny, ngn, ni, nj, ny \\
\hline$/ 2 /$ & hsh, s, sc, sci, scj, sh, ss, sf, sz, f, fc, fch, fci, fcj, fç, fs, ff, ffc, z, x \\
\hline$|3|$ & ç, g, s, sc, sci, sh, f, fc, fci, fcj, fg, fgi, fgj, fh, fs, z, x, xi \\
\hline
\end{tabular}

(usp. VonČInA 2002: 288)

S druge strane, u glagoljici i ćirilici / bosančici nalazimo samo po jedan znak za te foneme. Gornja tablica prikazuje kako unatoč tendenciji ka monografskim rješenjima nalazimo mnogo dvoslova i troslova među grafemima.

\section{DVOJNA TRADICIJA LATINICE U HRVATA}

\subsection{Južna tradicija}

Srednjovjekovna je Hrvatska bila podijeljena na dva velika područja glede političkog, gospodarskog i crkvenog utjecaja. Ova je podijeljenost odredila i razvoj latinične grafije. Razvila su se dva osnovna sustava latinične grafije, tj. dvije tradicije koje je karakterizirao različiti izgovor crkvenog latinskog jezika.

U Primorju, Dalmaciji i na otocima je očit talijanski utjecaj, budući da su ova područja bila stoljećima u neposrednome dodiru s Talijanima i Mletačkom Republikom. S druge strane, ne 
smijemo zaboraviti već postojeću latinsku pismenost na ovim područjima u kojoj možemo vidjeti i očuvanu romansku tradiciju i kontinuitet antike (KATIČIć 1998: 42). Na ovom području visoko je svećenstvo bilo talijanskog podrijetla, dok su niži svećenici svi bili hrvatskog porijekla, mada su svi dobro znali i talijanski (HADrovics 1994: 9). Iz jakog talijanskog crkvenog utjecaja slijedi da je izgovor latinskog jezika pratio talijansku tradiciju, što je utjecalo i na razvoj latiničke grafije. Talijansku tradiciju izgovora prikazuje promjena latinskih suglasničkih skupova /-gn-/ i /-sc-/: lat. /-gn-/ > tal. /n/; hrv. /n/, npr. lat. regnum 'kraljevina, kraljevstvo' > tal. regname; hrv. renjum; lat. /-sc-/ > hrv. /J/, npr. lat. descendo 'sići, silaziti' > hrv. dešendo (HADrovics 1994: 9).

Sljedeća tablica prikazuje grafeme južne tradicije:

\begin{tabular}{|c|c|}
\hline Fonem & Grafemi \\
\hline$/$ ts/ & $\mathrm{z}, \mathrm{ç}$ \\
\hline$/ \mathrm{t} /$ & $\mathrm{c}, \mathrm{ci}, \mathrm{ç}$ \\
\hline$/ \mathrm{c} /$ & $\mathrm{cch}, \mathrm{ch}, \mathrm{chi}, \mathrm{chy}$ \\
\hline$/ \mathrm{d} /$ & $\mathrm{g}, \mathrm{gi}$ \\
\hline$/ \mathrm{d} /$ & $\mathrm{g}, \mathrm{gi}$ \\
\hline$/ K /$ & $\mathrm{gl}, \mathrm{gli}$ \\
\hline$/ \mathrm{n} /$ & $\mathrm{gn}, \mathrm{gni}$ \\
\hline$/ \mathrm{s} /$ & $\mathrm{s}, \mathrm{f}, \mathrm{ss}, \mathrm{ff}$ \\
\hline$/ \mathrm{s} /$ & $\mathrm{sc}, \mathrm{fc}, \mathrm{s}, \mathrm{ss}, \mathrm{sci}$ \\
\hline$/ \mathrm{z} /$ & $\mathrm{s}, \mathrm{z}$ \\
\hline$/ \mathrm{z} /$ & $\mathrm{x}, \mathrm{s}, \mathrm{z}$ \\
\hline
\end{tabular}

(usp. Hadrovics 1994: 10-11)

Naravno, uporaba određenih grafema bila je uvjetovana različitim pravilima. U srednjovjekovnoj talijanskoj grafiji također nalazimo mnogo grafema za označavanje fonema /s/, /z/, /ts/. ${ }^{1}$ Uz to treba istaknuti i to da je talijansku grafiju čak od XIII. stoljeća karakterizirala i razlika uporabe grafema po pojedinim pokrajinama (MigLIORINI 1971: 147). Ovu značajku nalazimo i u XIV. i XV. stoljeću također (Migliorini 1971: 214, 269).

Fonem /ts/ su pisali grafemima $\langle\mathrm{z}\rangle \mathrm{i}\langle c ̧>$, naime posljednji se pojavljuje tek u starijim hrvatskim spomenicima i vjerojatno je južnofrancuskog podrijetla, a dospio je u hrvatsku grafiju sjevernotalijanskim posredovanjem (HADrovics 1994: 11).

Fonem / $\mathfrak{g} /$ su pisali grafemom $<\mathrm{c}>$ ispred /e/ i / $/$, a ispred stražnjih samoglasnika grafemom $<$ ci $>$, a rjeđe $\mathrm{i}<$ ç> (HADrovics 1994: 11).

Fonem /ć/ označavali su različitim grafemima. Zakonitosti vidimo u tome da su ispred /i/ pisali $<$ ch>, a ispred stražnjih samoglasnika <chi>, <chy> (Hadrovics 1994: 11).

Grafemi za označavanje fonema /d/ i /d子/ poklapaju se u starijim spomenicima: ispred /i/, /e/ su ih pisali grafemom $<$ g $>$, a ispred stražnjih samoglasnika grafemom $<$ gi $>$ (Hadrovics 1994: 11). Označavanje fonema $/ \mathrm{K} / \mathrm{i} / \mathrm{n} /$ grafemima $<$ gl $>$, $<$ gli $>\mathrm{i}<\mathrm{gn}>$, $<$ gni $>$ potpuno prati talijanski način označavanja.

1 http://www.treccani.it/enciclopedia/grafia_\%28Enciclopedia-dell\%27Italiano\%29. 
Najpromjenljivije je bilo označavanje fonema /s/ i / $/$. Fonem /s/ su označavali grafemima $<$ s $>$ i $<\uparrow>$, a u međusamoglasničkom položaju grafemima $<$ ss $>$ i <ff $>$ (Hadrovics 1994: 10). $\mathrm{Za}$ označavanje fonema / / najčešće se upotrebljavali grafemi $\langle\mathrm{sc}\rangle$ ili $\langle\mathrm{fc}\rangle$, ispred stražnjih samoglasnika <sci> (HAdrovics 1994: 10). Rjeđe se pojavljuju i grafemi <s> i <ss $>$ koje su upotrebljavali i za označavanje fonema /s/. Fonem /z/ su najprvo označavali grafemom $<\mathrm{s}\rangle$, a kasnije nalazimo i $<\mathrm{z}>$ (HADrovics 1994: 10).

Fonem $/ 3 /$ su u najstarijim spomenicima (Red i zakon..., Šibenska molitva) označavali grafemima $<\mathrm{s}>\mathrm{i}<\mathrm{z}>$, ali kasnije je prevladalo označavanje grafemom $<\mathrm{x}>$ (HADrovics 1994: 10). László Hadrovics objašnjava primjenu grafema $<\mathrm{x}>$ venecijanskim-dubrovačkim načinom izgovora / $\mathrm{x} / \mathrm{u}$ riječima croce, pace, voce koje su u starim dubrovačkim spomenicima napisane kao croxe, paxe, voxe (HADRovics 1994: 10).

\subsection{Sjeverna tradicija}

Tradicija je bila sasvim drugačija na sjevernom dijelu srednjovjekovne Hrvatske, zapravo na području Zagrebačke biskupije koju je osnovao kralj sv. Ladislav oko 1094. g. Na tom području vidimo utjecaj mađarskog izgovora latinskih glasova umjesto talijanskog načina izgovora. U srednjovjekovnom mađarskom jeziku su lat. /s/ izgovarali kao [S], a u međusamoglasničkom položaju i rjeđe na početku riječi kao [3], npr. lat. sanctus 'svetac' > mađ. sanktus $>$ hrv. šanktuš; lat. rosa 'ruža' > mađ. rózsa > hrv. roža; lat. synagoga 'sinagoga' > mađ. zsinagóga > hrv. žinagoga. Naravno, mađarski se način izgovora latinskog /s/ odražava i u latinskim imenima i posuđenicama, npr. lat. Moses > mađ. Móses [Mo:ze $]$ ] > hrv. Možeš; lat. Kaifas > mađ. Kaifas > hrv. Kaifaš; lat. fundus $>$ mađ. fundus $>$ hrv. funduš; lat. patronus $>$ mađ. patrónus $>$ hrv. patronuš (HAdrovics 1977: 15). ${ }^{2}$ Naravno, stanje u suvremenom hrvatskom standardnom jeziku je sasvim drugačije (o tome v. NYOMÁRKAY 1984: 26-73). Poznata je i činjenica da je Zagrebačka biskupija bila pod nadzorom Ostrogonske, kasnije Kalačke nadbiskupije, što je značilo da su i liturgijske knjige stizale do Hrvata mađarskim posredovanjem, a tako je naravno bio prihvaćen i mađarski način izgovora latinskih glasova. Time je također bio osiguran utjecaj srednjovjekovnog mađarskog latiniteta.

Ova tablica prikazuje grafeme sjeverne tradicije:

\begin{tabular}{|c|c|}
\hline Fonem & Grafemi \\
\hline$/ \mathrm{ts} /$ & $\mathrm{ch}, \mathrm{cz}$ \\
\hline$/ \mathrm{t} /$ & $\mathrm{ch}, \mathrm{cs}, \mathrm{cf}, \mathrm{ts}, \mathrm{tf}$ \\
\hline$/ \mathrm{c} /$ & $\mathrm{ch}$ \\
\hline$/ \mathrm{d} /$ & $\mathrm{gy}, \mathrm{gi}, \mathrm{dy}, \mathrm{dgy}$ \\
\hline$/ \mathrm{d} /$ & $\mathrm{gy}, \mathrm{gi}, \mathrm{dy}, \mathrm{dgy}$ \\
\hline$/ \Lambda /$ & $\mathrm{ly}, \mathrm{li}$ \\
\hline$/ \mathrm{n} /$ & $\mathrm{ny}, \mathrm{ni}$ \\
\hline
\end{tabular}

2 Ovaj se rad nalazi u rukopisnoj ostavštini akademika Lászla Hadrovicsa na Katedri za slavensku filologiju Filozofskog fakulteta Sveučilišta Loránd Eötvös u Budimpešti. Riječ je o izlaganju koje je profesor predstavio na međunarodnom znanstvenom skupu, održanom od 8. do 11. studenog 1977. g. u Veneciji. 


\begin{tabular}{|c|c|}
\hline$/ \mathrm{s} /$ & $\mathrm{z}, \mathrm{sz}, \mathrm{fz}$ \\
\hline$/ \mathrm{S} /$ & $\mathrm{s}, \mathrm{f}, \mathrm{ss}, \mathrm{ff}$ \\
\hline$/ \mathrm{z} /$ & $\mathrm{z}$ \\
\hline$/ \mathrm{z} /$ & $\mathrm{s}, \mathrm{f}$ \\
\hline
\end{tabular}

(usp. HAdrovics 1994: 11)

U sjevernoj tradiciji nalazimo također više grafema za označavanje određenih fonema, slično kao u južnoj tradiciji. Fonem /ts/ su označavali grafemima $<\mathrm{ch}>\mathrm{i}<\mathrm{cz}>$. Oba grafema nalazimo u srednjovjekovnoj mađarskoj grafiji. Starije je $<\mathrm{cz}>$ koje se pojavljuje tijekom XII. stoljeća, a $<$ ch> nalazimo tek od XIII. stoljeća (KNIEZsA 1959: 6).

Za označavanje fonema $/ \mathrm{t} / \mathrm{su}$ upotrebljavali grafeme $\langle\mathrm{ch}\rangle,\langle\mathrm{cs}\rangle,\langle\mathrm{cf}\rangle,\langle\mathrm{ts}\rangle \mathrm{i}<\mathrm{tf}\rangle$ (HaDrovics 1994: 11). Najstariji je grafem <ch> koji se u mađarskoj grafiji pojavljuje već u XII. stoljeću (KNIEZsA 1959: 6). Drugi grafemi za označavanje fonema / $\mathfrak{g} /$ pojavljuju se tek tijekom XVI. stoljeća u mađarskoj grafiji (KNIEzsA 1959: 17-18), a potom i u hrvatskoj sjevernoj tradiciji. Grafem <cs> pojavljuje se u mađarskoj katoličkoj grafiji u XVI. stoljeća, pa ga je nadbiskup i propovjednik Péter Pázmány počeo upotrebljavati u svojim tekstovima (KNIEzsa 1959: 34). Prvi mađarski akademski pravopis iz 1832. g. potvrdio je primjenu tog grafema (KNIEzsA 1959: 34) umjesto drugih rješenja, tako da ga upotrebljavaju i u suvremenom mađarskom pravopisu.

Za označavanje grafema /ć/ upotrebljavali su grafem <ch $>$ (HADrovics 1994: 11).

Foneme /d/ i /d子/ označavali su dvoslovima i troslovima $<$ gy $>,<$ gi $>,<$ dy $>,<$ dgy $>$ (Hadrovics 1994: 11). Grafem <gy> mađarskog je podrijetla, a pojavljuje se u mađarskoj grafiji u XIII. stoljeću (KNIEZsA 1959: 6). Troslov < dgy> nalazimo u mađarskoj protestantskoj i katoličkoj grafiji XVI. i XVII. stoljeća (KNIEzsa 1959: 23). Grafem <gi> naime možemo razumjeti kao dvoslov $g+j$, budući da su /j/ prije XVI. stoljeća najčešće označavali grafemom $<\mathrm{i}>$.

Foneme $/ K / \mathrm{i} / \mathrm{n} /$ označavali su grafemima $<\mathrm{ly}\rangle,<\mathrm{li}>,<$ ny $>,<$ ni $>$ (Hadrovics 1994: 11). Grafemi $<$ ly $>$ i $<$ ny $>$ mađarskog su podrijetla, a pojavljuju se tijekom XIII. stoljeća (KNIEzsA 1959: 6). U vezi s grafemima $<\mathrm{li}>\mathrm{i}<$ ni $>$ možemo reći da ih razumijemo kao dvoslove, $\mathrm{t} . l+j \mathrm{i} n+j$.

Fonem /s/ označavali su grafemima $<\mathrm{z}>,<$ sz $>$ i $<$ fz $>$ (HADrovics 1994: 11), a najstarije je $<\mathrm{z}>$ koje nalazimo već od početaka mađarske latinične grafije (usp. KNIEzsa 1959: 6). Grafemi <sz> i < ₹z> se pojavljuju tek u XVI. stoljeću (KNIEZsA 1959: 17-18) i oba su njemačkog podrijetla (KNIEZSA 1959: 34, SCHмidt 2000: 304).

Fonem / / označavali su grafemima $<\mathrm{s}>,<\mathrm{f}>,<\mathrm{ss}>\mathrm{i}<\mathrm{ff}>$ (HADrovics 1994: 11). Grafem $<\mathrm{s}>$ nalazimo već od početaka mađarske latinične grafije, $a<1>$ je njemačkog podrijetla i proširilo se tiskarstvom (Mollay 1989: 268). Grafeme <ss $>$ i $<$ ff $>$ pisali su u međusamoglasničkom položaju.

Označavanje fonema /z/ nije značilo poteškoću zato što su ga pisali grafemom $<\mathrm{z}>$ od samih početaka grafije.

Fonem /3/ označavali su grafemima $<$ s $>$ i $<$ l $>$ (Hadrovics 1994: 11). Grafem $<$ s $>$ nalazimo već u prvim spomenicima, dakle u XI. stoljeću, a grafem $<\uparrow>$ proširio se tiskarstvom (MollaY 1989: 268). 
Sljedeća tablica kontrastivno prikazuje grafeme obiju tradicije:

\begin{tabular}{|c|c|c|}
\hline Fonem & Grafemi - južna tradicija & Grafemi - sjeverna tradicija \\
\hline$/ \mathrm{ts} /$ & $\mathrm{z}, \mathrm{ç}$ & $\mathrm{ch}, \mathrm{cz}$ \\
\hline$/ \mathrm{t} /$ & $\mathrm{c}, \mathrm{ci}, \mathrm{c}$ & $\mathrm{ch}, \mathrm{cs}, \mathrm{cf}, \mathrm{ts}, \mathrm{tf}$ \\
\hline$/ \mathrm{c} /$ & $\mathrm{cch}, \mathrm{ch}, \mathrm{chi}, \mathrm{chy}$ & $\mathrm{ch}$ \\
\hline$/ \mathrm{d} /$ & $\mathrm{g}, \mathrm{gi}$ & $\mathrm{gy}, \mathrm{gi}, \mathrm{dy}, \mathrm{dgy}$ \\
\hline$/ \mathrm{d} /$ & $\mathrm{gl}, \mathrm{gli}$ & $\mathrm{gy}, \mathrm{dy}, \mathrm{dgy}$ \\
\hline$/ \mathrm{K} /$ & $\mathrm{gn}, \mathrm{gni}$ & $\mathrm{ny}, \mathrm{ni}$ \\
\hline$/ \mathrm{n} /$ & $\mathrm{s}, \mathrm{f}, \mathrm{ss}, \mathrm{ff}$ & $\mathrm{z}, \mathrm{sz}, \mathrm{fz}$ \\
\hline$/ \mathrm{s} /$ & $\mathrm{sc}, \mathrm{fc}, \mathrm{s}, \mathrm{ss}, \mathrm{sci}$ & $\mathrm{s}, \mathrm{f}, \mathrm{ss}, \mathrm{ff}$ \\
\hline$/ \mathrm{f} /$ & $\mathrm{s}, \mathrm{z}$ & $\mathrm{z}$ \\
\hline$/ \mathrm{z} /$ & $\mathrm{x}, \mathrm{s}, \mathrm{z}$ & $\mathrm{s}, \mathrm{f}$ \\
\hline$/ \mathrm{z} /$ & &
\end{tabular}

\subsection{Mješoviti sustavi}

To su dva sustava dvije tradicije koji su bili u primjeni na različitim područjima do kraja XVI. stoljeća, kada je prvi put došlo do njihova miješanja. Riječ je o prvom djelu hrvatske leksikografije, tj. rječniku Fausta Vrančića. Vrančić je u svom rječniku za označavanje određenih leksema upotrebljavao pojedine grafeme i jednog i drugog sustava. Mađarski utjecaj uporabe grafema u Vrančićevu petojezičnom rječniku predstavio je István Vig (v. VIG 2007), a o uporabi grafema u Vrančićevu rječniku možemo detaljnije čitati u Vigovem radu (v. VIg 2011: 34-37). Naime, Slavonija je postala područje na kojem je nastao mješoviti sustav obiju grafije koji nalazimo prvi put u Fausta Vrančića (Hadrovics 1994: 12). Naravno, nakon Vrančića bilo je još nekoliko pokušaja (npr. Šime Budinić, Rafael Levaković, Jakov Mikalja, Rajmund Đamanjić; o tome detaljnije v. Moguš 1993: 106-111) za ujednačivanje južne i sjeverne tradicije u jedan mješoviti sustav, mada se to i u Slavoniji okončalo tek u XVIII. stoljeću.

\section{ZAKLJUČAK}

Povijest hrvatske latinične grafije ima dvostruke korijene, što objašnjavamo povijesnim i kulturnim razlozima. Južna je Hrvatska bila u tijesnoj vezi s talijanskim gradovima, napose s Venecijom, što je značilo i kontakt s talijanskom kulturom, jezikom i književnošću. Uza sve to je bio jak i utjecaj talijanske katoličke crkve, a u srednjem vijeku crkva je njegovala i pismenost, čime je utjecala i na razvoj grafije. Najvažniji je bio način izgovora latinskih glasova koji je u južnoj Hrvatskoj pratio talijanski uzus. S druge strane, sjeverna je Hrvatska bila pod jakim utjecajem Ugarske i mađarske katoličke crkve, stoga je način izgovora latinskih glasova pratio mađarski uzus. U sjevernom grafijskom sustavu nalazimo drugačije označavanje pojedinih fonema nego u južnom grafijskom sustavu. Ova dva sustava su stoljećima karakterizirali hrvatsku latiničnu grafiju, dok u XVIII. stoljeću nije dolazilo do miješanja ova dva sustava u jedan mješoviti, možemo čak reći „slavonski“ tip, koji nije bilo dugo u primjeni, budući da je u XIX. stoljeću, zahvaljujući Ljudevitu Gaju, nastala prva jedinstvena latinična grafija koja je bila prihvaćena svugdje u Hrvatskoj. 


\section{LITERATURA}

BALÁzs 1989 = BALÁzs János: A latin a Duna-tájon. In: BALÁzs János (szerk.): Nyelvünk a Duna-tájon. Budapest, 1989. 95-140.

FARKAš-ĆURAK 2016 = FARKAš Loretana, ĆURAK Silvija: Mađarsko-hrvatska grafijska prožimanja u prošlosti. In: LuKÁcs István (ured.): Od početaka do danas. 120 godina kroatistike u Budimpešti. Budapest, 2016. 95-110.

FARKAŠ 2019 = FARKAŠ Loretana: Slavonska grafija u prvoj polovici 18. stoljeća. In: LuKÁcs István (ured.): Nomadi margine. Budapest, 2019. 121-151.

HADrovics 1942 = HAdrovics László: Zur Geschichte der einheitlichen kroatischen Schriftsprache. Johannes Belostenec (1594-1675) als Lexikograph und Prediger. Archivum Europae Centro-Orientalis 8 (1942): 168-209.

HADrovics 1944 = Hadrovics László: Zur Geschichte der kroatischen Rechtschreibung im XVIII. Jahrhundert. Archivum Europae Centro-Orientalis 10 (1944): 325-374.

HAdrovics 1951 = HADrovics László: A XVI. századi protestáns horvát nyomtatványok helyesírása. $A z$ MTA I. Osztály Közleményei 1 (1951): 164-172.

HAdrovics 1966 = Hadrovics László: Покушај реформе латиничког правописа 1785. године. Анали Филолошког факултета 5 (1966): 267-272.

Hadrovics 1977 = Hadrovics László: Gemeinsame Traditionen der Latinität in Ungarn und Kroatien. [Handschrift.] Budapest, 1977.

Hadrovics 1984 = Hadrovics László: Das altkroatische Passionslied. Studia Slavica Hung. 30 (1984): 8-37.

HADRovics 1994 = HADRovics László: Segédkönyv a szlavisztikai szemináriumi gyakorlatokhoz. Hadrovics László válogatott írásaiból. / Hilfsbuch zu slavistischen Seminarübungen. Ausgewählte Schriften von László Hadrovics. Budapest, 1994.

KAPETANOviĆ 2005 = KAPETANOviĆ Amir: Hrvatska srednjovjekovna latinica. Rasprave Instituta za hrvatski jezik i jezikoslovlje 31 (2005): 463-471.

KatıČIĆ 1998 = KatıČIć Radoslav: Književni jezik. Razvoj. In: LonČArić Mijo (ured.): Hrvatski jezik. Opole, 1998. 37-53.

KNIEZsA 1959 = KNIEZsA István: A magyar helyesírás története. Budapest, 1959.

LuKÁcs 2008 = LuKács István: Passióhagyomány a horvát irodalomban. Budapest, 2008.

MARASChIO 1994 = MARASChIo Nicoletta: Grafia e ortografia: evoluzione e codificazione. In: SERRIANI Luca (ed.): Storia della lingua italiana. Torino, 1994. 139-227.

MARETIĆ 1889 = MARETIĆ Tomo: Istorija hrvatskoga pravopisa latinskijem slovima. Zagreb, 1889.

Migliorini 1971 = Migliorini Bruno: Storia della lingua italiana. Firenze, 1971.

Moguš 1993 = Moguš Milan: Povijest hrvatskoga književnoga jezika. Zagreb, 1993.

Moguš-Vončina 1969 = Moguš Milan, Vončina Josip: Latinica u Hrvata. Radovi Zavoda za slavensku filologiju 11 (1969): 61-81.

Mollay 1989 = Mollay Károly: A német-magyar nyelvi érintkezések. In: BALÁzs János (szerk.): Nyelvünk a Duna-tájon. Budapest, 1989. 231-290.

NyomÁrKay 1984 = NyomÁrKaY István: Strane riječi u hrvatskosrpskom (srpskohrvatskom) jeziku. Budapest, 1984.

NYOMÁRKAY 2007 = NYOMÁRKAY István: Rövid horvát és szerb nyelvtörténet. Budapest, 2007.

OczKowa 2010 = Oczkowa Barbara: Hrvati i njihov jezik. Zagreb, 2010. 
SснміDт 2000 = SснміDт Wilhelm (Hrsg.): Geschichte der deutschen Sprache. Ein Lehrbuch für das germanistische Studium. Stuttgart, 2000.

VIG 2007 = VIG István: Ungarischer Einfluss im kroatischen Schriftsystem von Faust Vrančić. Studia Slavica Hung. 52 (2007): 447-456.

VIG 2011 = VIg István: Verancsics Faustus Dictionariuma a korabeli európai kontextusban. Budapest, 2011. VINCE 1978 = VINCE Zlatko: Putovima hrvatskoga književnog jezika. Zagreb, 1978.

VONČINA 2002 = VoNČINA Josip: Latinicom pisani hrvatski tekstovi od Marulića do Gaja. Forum 41 (2002): 286-321.

\section{ELŐD DUDÁS}

Department of Slavic Studies, Eötvös Loránd University, Budapest, Hungary

\section{The Dual Tradition of the Latin-Script Orthography in the Croatian Language: A Historical Overview}

The history of the Croatian Latin-script orthography is remarkably rich and contains several interesting facts for the researchers; however, only a handful of writings have been published in this matter. The first work written in the topic is Maretićs history of orthography (MARETić 1889). It is also important to mention the study by Milan Moguš and Josip Vončina (Moguš-Vončina 1969), in which they corrected several false statements written by Maretić. Recently, a few more papers on orthographic history have been published (KAPETANOviĆ 2005, FARKAŠ-ĆURAK 2016, FARKAš 2019); nevertheless, it is necessary to point out the work by László Hadrovics, the only researcher in the subject who paid great attention to the dual tradition of the Latin-script orthography in the Croatian language. Following the steps of Hadrovics, the main goal of this paper is to present which cultural historical reasons determined the development of the dual tradition of the Croatian Latin-script orthography as well as to introduce the use of graphemes in detail.

The church played an important role in the development of the Latin script. During the Middle Ages, the church counted as the centre of the literacy, thus it is obvious that the ecclesiastical Latin pronunciation defined the evolution of the individual national languages' orthographies. From this point of view, the Croatian is a special case, as in the Middle Ages, the Southern Croatian areas were strongly affected by the Italian, more precisely by the Venetian language, while in the northern areas, overlapping the Archdiocese of Zagreb, a strong Hungarian impact can be observed. The southern orthographic tradition follows the Italian pronunciation, i.e. the spelling is also based on the current Italian orthography. Nevertheless, in the northern areas, the Latin /s/ phoneme is pronounced in a Hungarian way, as [S] or [3]. The two orthographic systems were in use side by side over the centuries; nonetheless, since the end of the 16th century, there were several attempts to create a "mixed" system, which was successfully carried out only in the 18th-century Slavonian orthography.

Keywords: the Croatian language, orthography, Latin-script orthography, historical overview, dual tradition, the use of graphemes, Italian influence, Italian orthography, Hungarian influence, Hungarian orthography

Open Access. This is an open-access article distributed under the terms of the Creative Commons Attribution 4.0 International License (https://creativecommons.org/licenses/by/4.0), which permits unrestricted use, distribution, and reproduction in any medium, provided the original author and source are credited, a link to the CC License is provided, and changes - if any - are indicated. (SID_1) 